\title{
Testosterone Therapy in Adolescent Boys: The Need for a Structured Approach
}

\author{
Marianna Rita Stancampiano ${ }^{a, b}$ Angela K. Lucas-Herald ${ }^{b}$ Gianni Russo $^{a}$ \\ Alan D. Rogol ${ }^{c}$ S. Faisal Ahmed ${ }^{\text {b }}$ \\ ${ }^{a}$ Department of Pediatrics, Endocrine Unit, Scientific Institute San Raffaele, Milan, Italy; ${ }^{\text {b Developmental }}$ \\ Endocrinology Research Group, University of Glasgow, Glasgow, UK; ' ${ }^{\circ}$ Department of Pediatrics, University of \\ Virginia, Charlottesville, VA, USA
}

\section{Keywords}

Testosterone - Adolescent · Boys · Pubertal delay ·

Hypogonadism

\begin{abstract}
Background: In adolescents, testosterone may have several effects including promotion of secondary sexual characteristics and pubertal growth, attainment of optimal muscle mass and peak bone mass, optimization of the metabolic profile, and psychosocial maturation and well-being. Summary: Testosterone therapy is a cornerstone of the management of hypogonadism in boys. Since the initial report of the chemical synthesis of testosterone, several formulations have continued to develop, and although many of these have been used in boys, none of them have been studied in detail in this age group. Given the wide ranging effects of testosterone, the level of evidence for their effects in boys and the heterogeneity of conditions that lead to early-onset hypogonadism, a standardized protocol for monitoring testosterone replacement in this age group is needed. Key Messages: In this review, we focus on the perceived benefits of androgen replacement in boys affected by pubertal delay and highlight the need to improve the health monitoring of
\end{abstract}

\section{KARGER}

() 2019 S. Karger AG, Basel boys who receive androgen replacement therapy, proposing different approaches based on the underlying pathophysiology.

(c) 2019 S. Karger AG, Basel

\section{Introduction}

Puberty represents a complex physiological process that culminates in the attainment of sexual maturity and reproductive capability. It is regulated by several factors, including genetic and environmental cues $[1,2]$. Historically, the mean onset of puberty in boys is around 11.6 years, with $95 \%$ of boys entering puberty between 9.5 and 14 years of age [3]. In boys, delayed puberty is traditionally defined as the absence of testicular enlargement at over the age of 14 years, and it is estimated that delayed puberty affects approximately $2 \%$ of adolescent population [4]. Several conditions may determine the delay in pubertal maturation in boys, and a thorough knowledge of these factors is essential to develop a plan for its management $[5,6]$. Sex steroid therapy with testosterone (T) is considered one of the cornerstones of the management of adolescents with delayed puberty; in a routine tertiary

S. Faisal Ahmed, MD, FRCPCH

School of Medicine, University of Glasgow

New South Glasgow University Hospital Campus, 1345 Govan Road Glasgow G51 4TF (UK)

E-Mail faisal.ahmed@glasgow.ac.uk 
hospital setting in the United Kingdom, approximately $10-15 \%$ of boys reviewed for suspected hypogonadism may proceed to testosterone therapy [7].

The induction and maintenance of secondary sexual characteristics have a crucial impact on the physical and psychosocial well-being, both in adolescents and young adults. Hypogonadism can cause short- and long-term consequences such as increase the risk of metabolic syndrome $[8,9]$, and secondary osteoporosis [10] and boys affected by pubertal delay can also feel distressed by their condition. This may have an important impact on quality of life, even many years later, in adult age $[11,12]$. However, testosterone therapy, may also be associated with behavior disturbance [13, 14], acne [15], and if inappropriately administered, with bone age advancement, resulting in a shorter adult height than initially predicted.

\section{The Aetiology of Delayed Puberty}

The most frequent cause of delayed puberty in boys is physiological constitutional delay of growth and puberty (CDGP), which is transient and self-limiting, followed by functional hypogonadism secondary to another chronic illness, and finally, organic or genetic conditions associated with hypogonadotropic hypogonadism or hypergonadotropic hypogonadism $[7,16,17]$. However, this only includes those boys who are referred for a paediatric endocrine evaluation and given that the clinical extent of hypogonadism may be variable, it is possible, therefore, that the real prevalence of self-limited as well as prolonged hypogonadism may be higher. For certain conditions, the incidence of male hypogonadism may change over time in response to temporal shifts in therapy and clinical management. For instance, endocrine disorders are among the most frequent long-term sequelae reported in childhood cancer survivors $[18,19]$ and a quarter of long-term cancer survivors may suffer from hypogonadism [20] but this may change depending on advances in cancer therapy. Similarly, hypogonadism is increasingly recognized in boys with Duchenne Muscular Dystrophy who are surviving for longer with the help of high dose glucocorticoid therapy [21]. Another stark example of this changing prevalence is the finding that an increasing number of undervirilized XY infants with a disorder of sex development are now raised as male rather than female [22], thus raising the possibility of a larger number of young hypogonadal men in the future. Lastly, an increasing number of transgender adolescents may start on testosterone as part of cross-sex hormone therapy [23].

\section{Testosterone Action}

Although small amounts of testosterone are secreted by the zona reticularis of the adrenal glands, the majority is produced by the testes and secreted by Leydig cells. In the adult male, testosterone production rate ranges from 3.0 to $7 \mathrm{mg}$ /day $[24,25]$. About $7 \%$ of testosterone is converted, via $5 a$-reductase, to a more potent metabolite named dihydrotestosterone, with an estimated production rate of $200-300 \mu \mathrm{g} /$ day; approximately $0.5 \%$ of testosterone is metabolized to estrogen via aromatization [26-29]. The principal actions of testosterone are mediated via the androgen receptor (AR) encoded by the AR, which is a single copy gene located on the $\mathrm{X}$ chromosome [30]. In the cytoplasm, AR associates with heat shock proteins, which modulate the receptor's conformation for efficient ligand binding [31, 32]. Androgens cross the plasma membrane, enter the cytoplasm, and bind to the AR, leading to dissociation of chaperone proteins and translocation to the nucleus. At the nucleus, this complex undergoes dimerization and binds to androgen response elements [33], resulting in recruitment of histone acetyltransferase enzymes [31] and other essential coregulators that leads to gene transcription and, thereafter, protein synthesis [29]. The AR, like other nuclear receptors, is structurally comprised of three different functional domains: the $\mathrm{N}$-terminal domain, the DNA-binding domain, and the C-terminal ligandbinding domain, connected to the DNA-binding domain by a hinge region [34]. The $\mathrm{N}$-terminal domain is encoded by exon 1 of $A R$ and contains a polyglutamine (CAG) sequence whose length is highly variable in humans [35]. The normal size of the CAG sequence is estimated to be between 11 and 31 triplets and a lower as well as a higher number of CAG repeats are associated with an impaired AR function [36]. This may have an important impact on well-being, considering that $A R$ is expressed not only in male reproductive organs $[37,38]$, but also widely in several other human tissues (Fig. 1), including the cardiovascular system, gastrointestinal tract and smooth muscle [39]. Studies on Global AR Knockout male mice have investigated the pathological effects of AR dysfunction on bone [40,41], brain [42], muscle [43], cardiovascular system [44], glucose and lipid metabolism [45], immune and hemopoietic system $[46,47]$, underlying the key role of androgens on several discrete tissues. Testosterone can also exert its effects via nongenomic pathways, as demonstrated by many cells that do not express the nuclear AR. This rapid androgen response is not inhibited by classical AR 


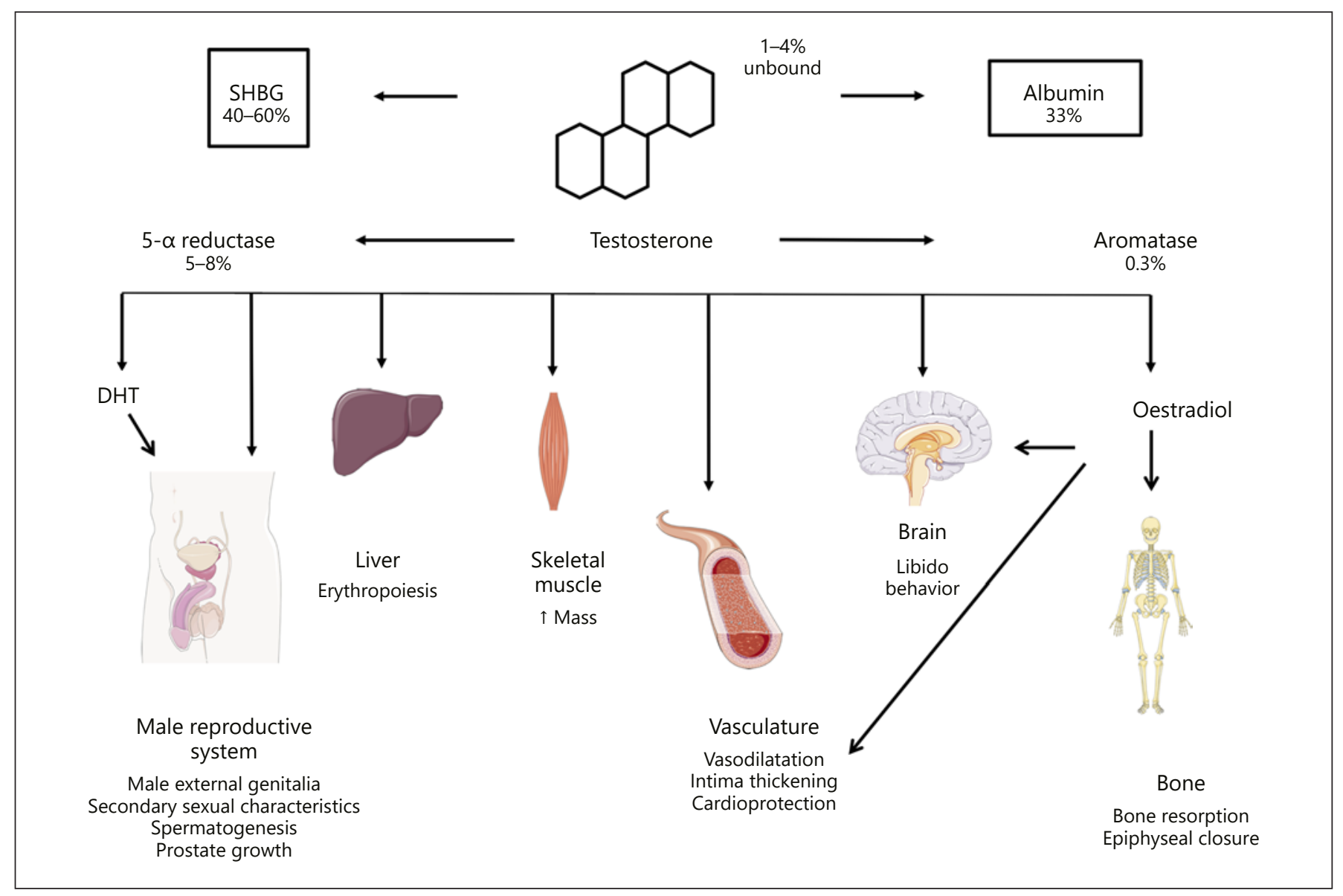

Fig. 1. Testosterone action on different organ systems. SHBG, sex hormone binding globulin; DHT, dihydrotestosterone.

antagonists [48]. The nature of these signals depends on the type of target cell and can include rapid $\mathrm{Ca}^{2+}$ release and consequently activation of the RAS/MEK (mitogenactivated protein kinase)/ERK (extracellular signal-regulated kinase)/MAPK (mitogen-activated protein kinase) pathway [48]; direct modification of ion channels including TRPM8 [49-51]; activation of the G-proteincoupled receptor GPRC6A [52]; or activation of the zinc transporter ZIP9 [53].

\section{The Effects of Testosterone}

Testosterone has several effects on many different tissues and systems, and in an ideal setting, sex steroid therapy should mimic this physiology. The effects of testosterone on the major systems are discussed below.

\section{Bone}

In children, bone mass tracks from childhood into late adolescence, and the onset of puberty is accompanied by increased bone accrual velocity [54], and the bone mass in pubertal children is higher than that of prepubertal children of the same age [55]. In healthy boys, almost 35\% of whole-body bone mineral content is achieved during the 4 years surrounding peak height velocity [56]. The peak bone mass that is attained following puberty is also considered a critical factor that determines the osteoporosis risk later in life [57]. There are several reports suggesting that delayed puberty is associated with lower BMD in adulthood [58-62]. However, other reports have not confirmed these observations and, furthermore, did not find any difference in BMD when comparing testosterone-treated and -untreated men affected by CDGP $[63,64]$. Although there is strong experimental evidence to suggest that androgens have both anabolic effects on 
bone, via AR, and indirect effects via conversion to estrogen by aromatase $[65,66]$, the effects of testosterone on bone health in humans and, particularly adolescents, are less clear $[67,68]$. In hypogonadal men, testosterone therapy may increase BMD [69-72], but whether it can restore BMD to the normal reference range, especially in those with early-onset hypogonadism, is not clear. Testosterone therapy has been reported to increase trabecular BMD in a subgroup of adolescents with open epiphyses, but this period of bone mineral accretion would have also coincided with an increase in height [73]. In addition, despite this increase, BMD still tends to remain below the normal reference range $[73,74]$. Given the added complexities of defining osteoporosis in children and young adults $[75,76]$ and in the absence of any reports of increased skeletal fragility (e.g., fracture rates), the challenge of identifying biologically relevant osteoporosis is much greater in those with early-onset hypogonadism. Two different studies of young adult hypogonadal males receiving testosterone treatment reported a BMD reduction in $10 \%$ of the study population [77, 78]. Varimo et al. [78] reported a prevalence of osteoporosis in 3 out of 30 male patients affected by congenital hypogonadotropic hypogonadism. At the time of the survey, the mean age of the population was 38.1 years (range 16-61 years), and the mean age at starting testosterone treatment was 18.3 years (range 11-34 years). Tam et al. [77], in a cross-sectional study, analyzed 21 young males diagnosed with hypogonadism under the age of 18 years, due to several underlying diseases and who were receiving testosterone therapy. The mean age of the population was $27.1 \pm 6.3$ years, $33 \%$ had osteopenia and $10 \%$ had osteoporosis as defined according to WHO criteria [79]. Recently, Antonio et al. [80], in a single-center retrospective observational study, evaluated 25 young men, diagnosed with congenital hypogonadotropic hypogonadism. Among these, only 6 had a DXA evaluation before starting treatment and all (100\%) had a T score $<-1$ at lumbar spine and $5(83 \%)$ had a femoral T-score $<-1$. The median age of this treatment-naïve group was 22.5 years (18-35). The remaining 19 patients started $\mathrm{T}$ treatment at a median age of 19 years (12-57). Analyzing the totality of patients who were continuously treated with testosterone $(n=23), 61$ and $48 \%$ of patients remained in the osteopenic/osteoporotic range for lumbar and femoral T-score, respectively (median follow-up time between first and last DXA 11 years, range 2-28 years). The authors speculated that a possible explanation for the persistent low BMD, even after a long-term treatment, could be the late age of starting testosterone therapy, supporting the hypothesis of an "adolescent window" of opportunity for peak bone mass attainment [81, 82].

In summary, there is good evidence that BMD is affected in young men with hypogonadism, and it is possible that it may increase following testosterone therapy. It is also possible that routine knowledge of BMD status in the adolescent who is on long-term testosterone therapy allows the clinician to make more informed decisions on the pace of dose escalation. However, the level of evidence on the value of regular assessment of BMD during adolescence in those who are on testosterone therapy is limited and may only improve if clear guidelines were introduced for monitoring and interpretation of BMD.

\section{Growth}

Sex steroids have a crucial role on several aspects of growth regulation, with the period of pubertal growth as an excellent example of this association $[83,84]$. They are able to control the pubertal growth rate acting at 2 different levels [84]: testosterone stimulates GH-IGF1 secretion via its conversion to oestrogen, that interacts with the estrogen receptors (estrogen receptor- $\alpha$ and estrogen receptor- $\beta$ ) expressed in the hypothalamus and the anterior pituitary gland $[85,86]$; at another level, both testosterone and estrogen directly interact with the AR and ERs localized in the growth plate cartilage [87].

Boys with CDGP usually present with relative short stature combined with delayed bone maturation. Observational studies on adolescents with such self-limited delayed puberty report a near adult height that is similar to the predicted adult height or mid-parental height [8891]. However, other studies suggest that these boys may not achieve their genetic height potential [92-94]. Several studies have examined the effects of testosterone therapy and reported no significant differences in adult height between treated and untreated boys, underlining that testosterone therapy does not adversely affect adult height [95-98]. In a recent review, Zhu et al. [99] compared and contrasted the studies published so far, analyzing the effect of pubertal delay and the eventual treatment on adult height. Boys with hypogonadotropic hypogonadism who are treated at a later age tend to be taller than average [100] and have abnormal body proportions, with relatively longer lower segment and increased arm span [101]. Thus, the aim of optimal therapy would be to increase linear growth during adolescence while ensuring adult height is within the mid-parental height range and that it is associated with normal body proportions [100, $102]$. 


\section{Secondary Sexual Characteristics}

One of the main goals of testosterone therapy in boys is to induce the adequate development of secondary sexual characteristics, including a satisfactory development of genital appearance. Some studies have demonstrated that, in boys, an abnormal appearance of the genitalia can directly affect the self-esteem and quality of life $[103,104]$. During treatment, a periodic clinical assessment is recommended [105], and it should include the evaluation of pubertal progression, according to Marshall and Tanner [3], as well as the measurement of the stretched penile length. Normal reference values for penile size related to age and Tanner stage and different ethnic groups do exist [106109], but such parameters are not used routinely to judge response to sex steroid therapy. While a change in penile length may be an objective and measurable clinical outcome in response to testosterone therapy, there is a greater need for standardization of the technique as well as an understanding of the precision of the technique. During testosterone therapy, adverse events such as testicular pain or priapism are not frequent. However, it is possible that some boys such as those with sickle cell disease, for example, may have a higher risk of priapism compared with unaffected boys [110]. It is speculated that priapism may be related to a higher dose of testosterone [111], but this effect has also been reported when using lower doses [112]. Gynecomastia is common in adolescent boys and, particularly, in those with conditions such as Klinefelter Syndrome and partial androgen insensitivity syndrome (PAIS) [113]. In PAIS, it is possible that the introduction of testosterone therapy itself may lead to a worsening of gynecomastia through aromatization to estrogens. On the other hand, it is possible that testosterone therapy may lead to a regression of gynecomastia in Klinefelter Syndrome [114], but this needs further studies.

In boys with hypogonadotropic hypogonadism, the aim of testosterone therapy is to primarily induce pubertal virilization rather than primarily increasing spermatogenesis. Pubertal induction with gonadotrophins has been proposed as a more appropriate means of optimizing fertility outcome compared to testosterone treatment despite its cost and inconvenience [115-118]. On the other hand, initial therapy with testosterone for pubertal induction followed by subsequent therapy with gonadotrophins has also shown satisfactory outcomes [119], but carefully designed trials are needed to investigate this conclusively.

\section{Metabolism}

Testosterone has marked anabolic effects [120, 121], and puberty is characterized by marked changes in body composition, with an increase in body size, muscle mass, and growth acceleration [122]. On the other hand, low testosterone levels are associated with metabolic impairment, increased fat mass, and reduced lean mass [123], even at a young age [124]. It is also possible that pubertal timing may have an impact on long-term metabolic and cardiovascular risk in men [99], but it is unclear whether treating adolescents with hypogonadism alters this longterm risk. Men with Klinefelter's syndrome, affected by primary gonadal failure, have a significantly increased risk of developing metabolic syndrome, compared to agematched peers $[125,126]$. Young men with untreated hypogonadotropic hypogonadism have an adverse metabolic profile, significantly lower HDL cholesterol, and a higher cardiometabolic risk, compared to healthy controls $[127,128]$. There is accumulating evidence that testosterone therapy in hypogonadal men increases fat-free mass and muscle strength and reduces whole body, intraabdominal, and intramuscular fat $[8,121,129,130]$. Observational studies have also documented an association between low testosterone level and nonalcoholic fatty liver disease (NAFLD) in adult men [131-133]. A recent retrospective case-control study reported a significantly higher prevalence of NAFLD in hypogonadal young males (34.9\%), compared with healthy matched controls (4.4\%) [128]. Interventional studies in hypogonadal men, receiving testosterone treatment in recommended dosages, have demonstrated a positive effect on liver fat and enzymes $[134,135]$. However, the prevalence of NAFLD in the range of conditions associated with hypogonadism and the therapeutic effect of testosterone on NAFLD require further studies. On the contrary, high doses of testosterone therapy may decrease the concentrations of ApoA1 and HDL cholesterol [136], and administration of anabolic steroids in supraphysiological doses results in an increased risk of liver diseases, including hepatocellular carcinoma [137]. Liver toxicity has been reported mostly with oral $17 \alpha$-alkylated androgens, and for this reason, this formulation is no longer used [129]. Currently available testosterone formulations are not associated with an increased hepatotoxicity risk, and the most recent clinical guidelines for adults receiving testosterone therapy do not recommend routine monitoring of liver function [129].

\section{Haematology}

Testosterone had been used for a long time for the treatment of chronic anemia, due to its erythrogenic effects [138]. For the same reason, it may cause erythrocytosis, clinically defined as an $\mathrm{Hb}$ level higher than $18.5 \mathrm{~g} /$ 
$\mathrm{dL}$; a hematocrit higher than $52 \%$ in men; or by an erythrocyte mass that exceeds $125 \%$ of that predicted for sex and body mass [138]. The risk of erythrocytosis may vary between different formulations [139]. Pharmacokinetic profile and dosage are considered the major factors linked to the risk of erythrocytosis, determining the amount and the duration of supraphysiological testosterone levels $[129,138,140]$. It is generally recommended to check hematocrit at baseline, 3-6 months after starting treatment, and then annually and a hematocrit level higher than 54\% should be considered a reason to pause therapy [129]. The incidence of erythrocytosis in adolescent boys treated with testosterone is not well reported, probably due to the low frequency of monitoring complete blood counts [7, 141].

\section{Psychosocial Status}

In clinical practice, boys with delayed puberty referred to the hospital for clinical management, often seem to be less comfortable and more distressed by the delay and after starting testosterone therapy they generally report feeling more confident with themselves and their peers. Late pubertal timing has been associated with lasting psychosocial consequences in men [99]. A UK Biobank study described a significative association between later voice breaking (as a self-reported sign of puberty delay) and higher risk of anxiety, panic attacks, and depression in affected men [142]. Two separate studies have suggested that late pubertal maturation may be related to a higher risk of depression [143] and substance abuse [144]. On the other hand, a systematic study of quality of life (QoL) in hypogonadal young males compared to agematched general population did not find any significant differences; however, younger adolescents did exhibit lower scores in some domains concerning vitality and physical functioning [77]. Among a group of young males with congenital hypogonadotropic hypogonadism, Varimo et al. [78] did report impaired QoL in dimensions associated with psychological well-being. Interestingly, the age at diagnosis is correlated negatively with the QoL score, and the authors concluded that late diagnosis and a consequent delayed start of testosterone therapy may have a lasting adverse influence in adulthood. While these studies emphasize the importance of addressing the psychosocial needs of the adolescent with delayed puberty, they also highlight the lack of structured assessment of these needs and the response to androgen replacement therapy.

\section{Testosterone Therapy}

Since the initial reports of the chemical synthesis of testosterone in the 1930s [145], [146], several testosterone formulations have become available, but none of them are licensed under current regulations for use in children. After subcutaneous testosterone pellets were first introduced in the 1940s, intramuscular injections of testosterone esters ( $\mathrm{T}$ propionate, $\mathrm{T}$ enanthateand $\mathrm{T}$ cypionate) became available in the 1950 s, oral $\mathrm{T}$ undecanoate was developed in the 1980s, transdermal patches were introduced in the 1990s, and the 2000s saw the introduction of topical gels, buccal patches, and a long-acting intramuscular preparation of T undecanoate [147]. In 2016, a nasal $\mathrm{T}$ preparation was introduced [148], and recently, in March 2019, the FDA announced the approval of a new testosterone undecanoate (TU) soft gel oral formulation as replacement therapy in men with hypogonadism [149]. Although all of these formulations may be considered to be effective, each formulation shows a different pharmacokinetic profile [150], and in adults, therapy is based on patient preference, the pharmacokinetics of the formulation, the treatment burden, and the cost, with the overall aim of ensuring adequate testosterone replacement [129]. Boys with CDGP and early-onset hypogonadism initially require a low dose of testosterone for pubertal induction followed by dose escalation in those requiring longerterm therapy $[105,151]$. For this reason, formulations where a steady dose increase can be incorporated (starting from a low initial dose) are generally favored. Hormonal induction of puberty in boys with permanent hypogonadism should be started at an appropriate age for a physiological onset of puberty [105]. In practice, testosterone therapy is often started around the chronological age of 12 in these boys [7]. Postponing the timing of pubertal induction could be considered in those boys with concomitant GH deficiency or severe short stature and bone delay, to increase the near adult height $[152,153]$. In boys with CDGP, testosterone therapy has usually been introduced around the age of 14 years [99].

\section{Testosterone Preparations That Have Been Used in Male Adolescents}

The vast majority of experience in the initiation and progression of pubertal development has been with the intermediate-acting esters of testosterone ( $\mathrm{T}$ enanthate and cypionate), or with a mixture of very short and shortacting esters (Sustanon $\left.{ }^{\circledR}\right)[105,154,155]$. Few data have been published so far, regarding the clinical use of other testosterone formulations in adolescent populations (Ta- 
Table 1. Testosterone therapy in boys with CDGP and hypogonadism

\begin{tabular}{|c|c|c|}
\hline Testosterone ( $\mathrm{T}$ ) formulation & CDGP & Hypogonadism \\
\hline $\begin{array}{l}\mathrm{T} \text { enanthate, cypionate or mixture of } \\
\mathrm{T} \text { esters, i.m. injection }\end{array}$ & $\begin{array}{l}\text { Initial dose: } 50 \mathrm{mg} \text { monthly, for } 3-6 \text { months. } \\
\text { Possible to increase the dosage by } 25-50 \mathrm{mg} \text {. } \\
\text { Not recommended to exceed } 100 \mathrm{mg} \text { monthly } \\
{[5,105]}\end{array}$ & $\begin{array}{l}\text { Initial dose: } 25-50 \mathrm{mg} \text { monthly. Increase of } 50 \mathrm{mg} \text { every } 6-12 \\
\text { months }[5,105] \\
\text { Adult dosage: } 150-200 \mathrm{mg} \text { every } 2 \text { weeks [129] }\end{array}$ \\
\hline T undecanoate, i.m. injection & No data available & $\begin{array}{l}\text { Used for pubertal induction only in young men [156-158] } \\
\text { Adult dosage: } 750 \mathrm{mg} \text { every } 10 \text { weeks [129] } \\
1,000 \mathrm{mg} \text { every } 10-14 \text { weeks [156] }\end{array}$ \\
\hline T transdermal gels & $\begin{array}{l}\text { Only one study available [167] } \\
\text { Gel } 2 \% \text { (Tostrex"): } 10 \text { mg daily, for } 3 \text { months }\end{array}$ & 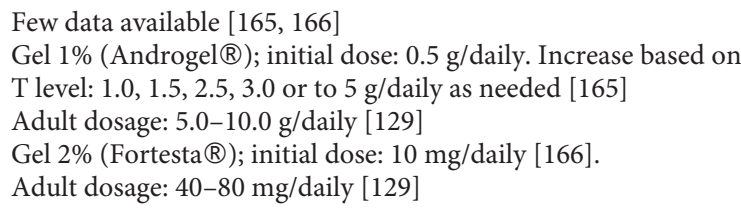 \\
\hline $\mathrm{T}$ transdermal patches & $\begin{array}{l}\text { Prepubertal } 12.5-15 \text { years: } 5 \text { mg over } 8-12 \mathrm{~h} \text {, } \\
\text { overnight, for } 8 \text { weeks [164] }\end{array}$ & $\begin{array}{l}\text { Prepubertal } 14-16 \text { years: } 2.5 \mathrm{mg} \text { over } 12 \mathrm{~h} \text {, overnight } \\
\text { Partially virilized } 17-19 \text { years: } 2.5 \mathrm{mg} \text { /daily } \\
\text { Virilized men }>20 \text { years: } 5 \mathrm{mg} / \text { daily [163] }\end{array}$ \\
\hline $\mathrm{T}$ pellets subcutaneous & No data available & $\begin{array}{l}\text { 13.9-17.5 years: } 8-10 \mathrm{mg} / \mathrm{kg} \text { every } 6 \text { months, for } 18 \text { months } \\
\text { [168] }\end{array}$ \\
\hline T nasal gel & No data available & No data available in adolescent population \\
\hline T transbuccal bioadhesive tablets & No data available & No data available in adolescent population \\
\hline
\end{tabular}

CDGP, constitutional delay of growth and puberty.

ble 1). The long-acting TU intramuscular formulation in promoting puberty maturation has been used only in older boys with permanent hypogonadism [156-158] and is clearly not appropriate for treatment of boys with CDGP. The efficacy and safety of oral TU formulation, in boys affected by puberty delay, have been explored in few studies $[159,160]$. Ahmed et al. [161], in a randomized, crossover comparison study, concluded that the oral formulation had a similar effectiveness on linear growth compared with an intramuscular depot preparation. Lawaetz et al. [17], in an open observational study, reported that the TU oral formulation was effective in inducing secondary sexual characteristics and promoting height velocity, without accelerating bone age advancement. Gregory et al. [162] documented a significant increase of height velocity and fat-free mass in boys with CDGP treated with TU oral formulation for 3 months. In a small study including 9 patients affected by beta thalassemia, diagnosed with hypogonadotropic hypogonadism, De Sanctis et al. [163] reported that the transdermal application of testosterone (Androderm ${ }^{\circledR}$ in different regimens) was effective in promoting growth and virilization. Mayo et al. [164], in a cross-over study including 8 boys treated with a transdermal patch (Virormone ${ }^{\circledR}$ in different regimens), described a significant increase in salivary testosterone, with concomitant improvement of short-term growth and bone turnover markers. In 2014, Rogol et al. [165] reported the efficacy of testosterone gel $1 \%$ in promoting secondary sexual characteristics in a group of boys affected by Klinefelter's syndrome or anorchia. During treatment, the most common adverse events registered were cough, acne, headache, and local cutaneous dermatitis. In 2016, Contreras et al. [166] described the effective and safe use of testosterone transdermal gel $2 \%$ (Fortesta ${ }^{\circledR}$ ) and $1 \%\left(\right.$ Androgel $\left.^{\circledR}\right)$ in three late adolescent hypogonadal boys with concomitant hypertransaminasemia. Re- 
cently, Chioma et al. [167] reported that in boys affected by CDGP, testosterone transdermal gel $2 \%$ was as effective as intramuscular testosterone in increasing height velocity, compared with untreated subjects. Other testosterone formulations that have been used include long-acting subcutaneous testosterone pellets [168]. In the past, boys with delayed puberty who had growth delay have been treated with oxandrolone, a nonaromatizable androgen [169-171], but its use has declined. Dihydrotestosterone (gel 2.5\%) has been used in boys with 5-alfa reductase deficiency and PAIS to increase penile length $[172,173]$. Recently, Varimo et al. [174] compared the use of intramuscular testosterone $(1 \mathrm{mg} / \mathrm{kg} / 4$ weeks) to oral letrozole $(2.5 \mathrm{mg} /$ day), for promoting puberty in boys with CDGP through a randomized, open-label trial. Over the study period of 6 months, letrozole was associated with a greater rise in gonadotrophins and testicular growth, but other outcomes such as growth and bone age advance were similar. In boys with hypogonadotropic hypogonadism, pulsatile GnRH or hCG in combination with FSH or FSH in combination with testosterone has also been used [151, $175,176]$; the relative benefits of the several different regimens require further clarification.

\section{Monitoring of Testosterone Therapy in Boys}

In clinical practice, the principal parameters used to assess the effectiveness of testosterone therapy are represented by the progression of pubertal maturation, height velocity, and changes in body composition. For this purpose, regular clinical follow-up is generally performed every 3-6 months [105]. However, together with the clinical assessment, other laboratory and imaging-based examinations (like DXA for bone mineral density and handwrist radiograph for bone age) may be helpful for monitoring both benefits and side effects of testosterone treatment. In guidelines developed for adult men receiving testosterone therapy, monitoring is highly recommended and standardized [129], whereas in adolescents there is a scarcity of such guidance $[105,177]$ and clear evidence that systematic monitoring is rarely undertaken $[7,141]$. In the study by Lucas-Herald et al. [7], of the 46 boys treated with testosterone at a single center, only $26 \%$ had liver function tests, $13 \%$ had a hematocrit, and $13 \%$ a $\mathrm{BMD}$ in the year prior to starting hormone therapy. Moreover, during testosterone therapy, liver function tests were assessed only in $13 \%$ and a hematocrit in $6 \%$ of the population [7]. Similar results were reported by Nahata et al. [141], analyzing retrospectively the management of hypogonadal boys, on testosterone therapy, at another center: $12 \%$ had no testosterone levels checked prior to starting hormone therapy, $17 \%$ did not have a testosterone level checked during treatment, $63 \%$ did not have a BMD at any point, and $31 \%$ did not have a hematocrit checked after starting testosterone therapy. It is possible that this variation in monitoring is due to the wide range of conditions that necessitate sex steroid therapy in adolescents. Bertelloni et al. [177], discussing the hormonal management in patients affected by disorders of sex development, proposed a scheme to monitor the effectiveness as well as safety of androgen therapy in males. To date, we are not aware of any other publication suggesting a targeted approach based on the underlying condition that leads to hypogonadism. With a greater appreciation of a wider range of effects of testosterone and the advent of several newer forms of testosterone replacement, the need for careful monitoring is becoming greater. This may especially be the case if there is a regulatory requirement for postmarketing surveillance of any preparations that are approved for boys.

We propose 2 different schemes of androgen replacement therapy monitoring, based on the temporary or permanent requirement for ongoing testosterone therapy (Tables 2, 3). We recommend an assessment of total blood count (including Hct and $\mathrm{Hb}$ levels) and liver function before starting testosterone for the determination of a "baseline," in all boys. This would identify the presence of underlying disease (such as polycythemia or hypertransaminasemia) that may contraindicate testosterone therapy or direct the physician to the diagnosis of an underlying condition, to choose the formulation with minor side effects and then start a personalized monitoring scheme. Moreover, those boys who are suspected to have CDGP, but require therapy for longer than 6 months, should not only have a thorough evaluation for the underlying cause but also follow the same monitoring protocol for hypogonadal patients, including the assessment of metabolic profile and bone mineral density (expressed as Z-score and adjusted for bone age) as it is possible that they may continue on testosterone for a longer period. In boys with permanent hypogonadism, the assessment of bone mineral density by DXA is performed on a relatively ad hoc basis $[113,141]$, and there is a need to perform this at regular intervals using validated methods adjusted for age, size, and sex [178]. To assess the psychosocial impact, we propose that the use of a standardized QoL tool such as the EQ-5D-Y should become routine practice [179]. In clinical practice, in boys with permanent hypogonadism, the effectiveness of testosterone treatment should be based mainly on clinical response, in terms of progression of Tanner stage (considered as enlargement of the stretched 
Table 2. Proposed scheme of testosterone therapy monitoring in boys with CDGP, generally treated for 3 or 6 months with subsequent revaluation

\begin{tabular}{llll}
\hline & Baseline & 3 months & 6 months \\
\hline Full clinical evaluation pubertal assessment* & $\sqrt{ }$ & $\sqrt{ }$ & $\sqrt{ }$ \\
Bone age & $\sqrt{ }$ & & \\
Total blood count (Hb, Hct) & $\sqrt{ }$ & & \\
Liver function test (AST, ALT, GGT) & $\sqrt{ }$ & &
\end{tabular}

Those boys who require therapy for longer than 6 months for "CDGP" should have a thorough evaluation for the underlying cause and follow the care pathway in Table 3 , starting from the baseline. * Tanner stage, stretched penile length. Hb, haemoglobin; Hct, haematocrit; AST, aspartate transaminase; ALT, alanine transaminase; GGT, Gamma-glutamyltransferase; CDGP, constitutional delay of growth and puberty.

Table 3. Proposed scheme of testosterone therapy monitoring in boys with hypogonadism, until complete pubertal development

\begin{tabular}{|c|c|c|c|c|c|c|c|}
\hline & Baseline & $\begin{array}{l}3 \\
\text { months }\end{array}$ & $\begin{array}{l}6 \\
\text { months }\end{array}$ & $\begin{array}{l}12 \\
\text { months }\end{array}$ & $\begin{array}{l}\text { Then every } \\
6 \text { months }\end{array}$ & $\begin{array}{l}\text { Then } \\
\text { annually }\end{array}$ & $\begin{array}{l}\text { Then every } \\
1-2 \text { years }\end{array}$ \\
\hline Full clinical evaluation Pubertal assessment* & $\sqrt{ }$ & $\sqrt{ }$ & $\sqrt{ }$ & $\sqrt{ }$ & $\sqrt{ }$ & & \\
\hline Bone age & $\sqrt{ }$ & & & $\sqrt{ }$ & & & $\sqrt{ }$ \\
\hline $\mathrm{BMD}^{\bullet}$ & $\sqrt{ }$ & & & $\sqrt{ }$ & & & $\sqrt{ }$ \\
\hline Total testosterone ${ }^{\#}$ & $\sqrt{ }$ & $\sqrt{ }$ & $\sqrt{ }$ & $\sqrt{ }$ & $\sqrt{ }$ & & \\
\hline LH, FSH & $\sqrt{ }$ & & & & & & \\
\hline Total blood count (Hb, Hct) & $\sqrt{ }$ & $\sqrt{ }$ & $\sqrt{ }$ & $\sqrt{ }$ & & $\sqrt{ }$ & \\
\hline Liver function test (AST, ALT, GGT) & $\sqrt{ }$ & & & & & & \\
\hline Metabolic profile (TC, LDL, HDL, TGD) & $\sqrt{ }$ & & & $\sqrt{ }$ & & & $\sqrt{ }$ \\
\hline
\end{tabular}

* Tanner stage, stretched penile length. BMD, bone mineral density should be expressed as SDS for age and sex and may require adjustment for size or bone age. " Total testosterone during treatment should be maintained in the mid-normal reference range for pubertal stage. Timing of measurement depends by the type of T formulation used. Hb, haemoglobin; Hct, haematocrit; AST, aspartate transaminase; ALT, alanine transaminase; GGT, Gamma-glutamyltransferase; TC, total cholesterol; LDL, low-density lipoprotein cholesterol; HDL, high-density lipoprotein cholesterol; TGD, triglycerides.

penile length) and secondary sexual characteristics (muscle mass accretion, facial and body hair growth, deepening of the voice). However, during treatment, it could be safe to maintain serum total testosterone level in the mid-normal reference range for pubertal stage [105]. This is why we recommend its periodic laboratory evaluation, ideally at 3 and 6 months after starting treatment and then every 6 months until completion of puberty. Timing of measurement of serum testosterone level may vary, depending on the type of formulation used and if testosterone levels are measured, careful consideration to the collection of samples in relation to the administration of the drug is required. The sample should be collected between injections for intramuscular testosterone enanthate or cypionate and before the next injection for intramuscular TU (to check after the third dose: first 2 injection spaced 6 weeks apart, subsequent given after 12 weeks); for the transdermal testosterone patch, the testosterone level should be checked 3-12 h post-application, 2 weeks after starting treatment; for transdermal testosterone gel, the testosterone level should be checked $2 \mathrm{~h}$ post-application, 2 weeks after starting treatment; for oral TU, the testosterone level should be checked $3-5 \mathrm{~h}$ after ingestion in the nonfasting state, 2 weeks after starting treatment.

\section{Conclusion}

Adolescence represents a crucial period in human life history, the transition between childhood and emerging adulthood, characterized by multiple challenges and developments in the physical and social domains. Testosterone therapy in adolescent boys is primarily aimed at increasing linear growth and pubertal progression, but may also have a positive effect on bone mineral content, muscle function, metabolic profile, and psychological well-being. 
Therapy should limit the long-term consequences of early-onset hypogonadism and the psychosocial distress of pubertal delay that may affect teenage behavior, lasting into emerging adulthood. Hypogonadal adolescent males may start on testosterone therapy for several conditions; some may only require testosterone therapy temporarily, while others may need lifetime therapy and the monitoring of therapy will, therefore, depend on the underlying condition. Thus, not only is there a need for clear guidance on how to investigate adolescent males with delayed puberty but there is also a need to have a clear protocol for monitoring boys receiving testosterone therapy, especially in those who may have permanent hypogonadism.

\section{Acknowledgments}

We thank all the reviewers for comments that greatly improved the manuscript.

\section{Disclosure Statement}

ADR is a consultant for Acerus Pharma, Anteres Pharma, Inc, Aytu BioScience, Clarus Therapeutics, and the United States and World Anti-doping Agencies. SFA has received consultant fees from Acerus Pharma.

\section{Funding Sources}

The funders had no role in preparation of the review.

\section{Author Contributions}

M.R.S. and A.K.L.-H. participated in drafting the review. G.R., A.D.R. and S.F.A. revised it critically for the intellectual content and gave final approval of the version to be submitted.

\section{References}

1 Visser HK. Some physiological and clinical aspects of puberty. Arch Dis Child. 1973 Mar; 48(3):169-82.

2 Ojeda SR, Lomniczi A. Puberty in 2013: unravelling the mystery of puberty. Nat Rev Endocrinol. 2014 Feb;10(2):67-9.

3 Marshall WA, Tanner JM. Variations in the pattern of pubertal changes in boys. Arch Dis Child. 1970 Feb;45(239):13-23.

4 Abitbol L, Zborovski S, Palmert MR. Evaluation of delayed puberty: what diagnostic tests should be performed in the seemingly otherwise well adolescent? Arch Dis Child. 2016 Aug;101(8):767-71.

5 Palmert MR, Dunkel L. Clinical practice. Delayed puberty. N Engl J Med. 2012 Feb;366(5): 443-53.

6 Howard SR, Dunkel L. The Genetic Basis of Delayed Puberty. Neuroendocrinology. 2018; 106(3):283-91.

7 Lucas-Herald AK, Mason E, Beaumont P, Mason A, Shaikh MG, Wong SC, et al. SingleCentre Experience of Testosterone Therapy for Boys with Hypogonadism. Horm Res Paediatr. 2018;90(2):123-7.

8 Rastrelli G, Filippi S, Sforza A, Maggi M, Corona G. Metabolic Syndrome in Male Hypogonadism. Front Horm Res. 2018;49:131-55.

9 Dwyer AA, Quinton R. The Metabolic Syndrome in Central Hypogonadotrophic Hypogonadism. Front Horm Res. 2018;49:156-69.

10 Golds G, Houdek D, Arnason T. Male Hypogonadism and Osteoporosis: The Effects, Clinical Consequences, and Treatment of Testosterone Deficiency in Bone Health. Int J Endocrinol. 2017;2017:4602129.
11 Lee PD, Rosenfeld RG. Psychosocial correlates of short stature and delayed puberty. Pediatr Clin North Am. 1987 Aug;34(4):851-63.

12 Dwyer AA, Quinton R, Pitteloud N, Morin D. Psychosexual development in men with congenital hypogonadotropic hypogonadism on long-term treatment: a mixed methods study. Sex Med. 2015 Mar;3(1):32-41.

13 Batrinos ML. Testosterone and aggressive behavior in man. Int J Endocrinol Metab. 2012; 10(3):563-8.

14 Elboga G, Sayiner ZA. Rare cause of manic period trigger in bipolar mood disorder: testosterone replacement. BMJ Case Rep. 2018 Aug 3;2018:bcr-2018-225108.

15 Kazandjieva J, Tsankov N. Drug-induced acne. Clin Dermatol. 2017 Mar - Apr;35(2):156-62.

16 Sedlmeyer IL, Palmert MR. Delayed puberty: analysis of a large case series from an academic center. J Clin Endocrinol Metab. 2002 Apr; 87(4):1613-20

17 Lawaetz JG, Hagen CP, Mieritz MG, Blomberg Jensen M, Petersen JH, Juul A. Evaluation of 451 Danish boys with delayed puberty: diagnostic use of a new puberty nomogram and effects of oral testosterone therapy. J Clin Endocrinol Metab. 2015 Apr;100(4):1376-85.

18 Rose SR, Horne VE, Howell J, Lawson SA, Rutter MM, Trotman GE, et al. Late endocrine effects of childhood cancer. Nat Rev Endocrinol. 2016 Jun;12(6):319-36.

19 Sklar CA, Antal Z, Chemaitilly W, Cohen LE, Follin C, Meacham LR, et al. HypothalamicPituitary and Growth Disorders in Survivors of Childhood Cancer: An Endocrine Society Clinical Practice Guideline. J Clin Endocrinol Metab. 2018 Aug;103(8):2761-84.
20 Isaksson S, Bogefors K, Ståhl O, Eberhard J, Giwercman YL, Leijonhufvud I, et al. High risk of hypogonadism in young male cancer survivors. Clin Endocrinol (Oxf). 2018 Mar; 88(3):432-41

21 Wood CL, Straub V, Guglieri M, Bushby K, Cheetham T. Short stature and pubertal delay in Duchenne muscular dystrophy. Arch Dis Child. 2016 Jan;101(1):101-6.

22 Kolesinska Z, Ahmed SF, Niedziela M, Bryce J, Molinska-Glura M, Rodie M, et al. Changes over time in sex assignment for disorders of sex development. Pediatrics. 2014 Sep; 134(3):e710-5.

23 Skordis N, Butler G, de Vries MC, Main K, Hannema SE. ESPE and PES International Survey of Centers and Clinicians Delivering Specialist Care for Children and Adolescents with Gender Dysphoria. Horm Res Paediatr. 2018;90(5):326-31.

24 Rivarola MA, Saez JM, Meyer WJ, Jenkins ME, Migeon CJ. Metabolic clearance rate and blood production rate of testosterone and androst-4-ene-3,17-dione under basal conditions, ACTH and HCG stimulation. Comparison with urinary production rate of testosterone. J Clin Endocrinol Metab. 1966 Nov; 26(11):1208-18.

25 Vierhapper H, Nowotny P, Waldhäusl W Determination of testosterone production rates in men and women using stable isotope/ dilution and mass spectrometry. J Clin Endocrinol Metab. 1997 May;82(5):1492-6. 
26 Winters SJ, Takahashi J, Troen P. Secretion of testosterone and its delta 4 precursor steroids into spermatic vein blood in men with varicocele-associated infertility. J Clin Endocrinol Metab. 1999 Mar;84(3):997-1001.

27 Heinlein CA, Chang C. The roles of androgen receptors and androgen-binding proteins in nongenomic androgen actions. Mol Endocrinol. 2002 Oct; 16(10):2181-7.

28 Oettel M. The endocrine pharmacology of testosterone therapy in men. Naturwissenschaften. 2004 Feb;91(2):66-76.

29 Lucas-Herald AK, Alves-Lopes R, Montezano AC, Ahmed SF, Touyz RM. Genomic and non-genomic effects of androgens in the cardiovascular system: clinical implications. Clin Sci (Lond). 2017 Jul;131(13):1405-18.

30 Werner R, Holterhus PM. Androgen action. Endocr Dev. 2014;27:28-40.

31 Bennett NC, Gardiner RA, Hooper JD, Johnson DW, Gobe GC. Molecular cell biology of androgen receptor signalling. Int J Biochem Cell Biol. 2010 Jun;42(6):813-27.

32 Pietri E, Conteduca V, Andreis D, Massa I, Melegari E, Sarti S, et al. Androgen receptor signaling pathways as a target for breast cancer treatment. Endocr Relat Cancer. 2016 Oct; 23(10):R485-98.

33 Grino PB, Griffin JE, Wilson JD. Testosterone at high concentrations interacts with the human androgen receptor similarly to dihydrotestosterone. Endocrinology. 1990 Feb; 126(2):1165-72.

34 Mangelsdorf DJ, Thummel C, Beato M, Herrlich P, Schütz G, Umesono K, et al. The nuclear receptor superfamily: the second decade. Cell. 1995 Dec;83(6):835-9.

35 Gelmann EP. Molecular biology of the androgen receptor. J Clin Oncol. 2002 Jul;20(13): 3001-15.

36 Tirabassi G, Cignarelli A, Perrini S, Delli Muti $\mathrm{N}$, Furlani G, Gallo M, et al. Influence of CAG Repeat Polymorphism on the Targets of Testosterone Action. Int J Endocrinol. 2015; 2015:298107.

37 Matsumoto AM. Testosterone administration in older men. Endocrinol Metab Clin North Am. 2013 Jun;42(2):271-86.

38 Matsumoto T, Sakari M, Okada M, Yokoyama A, Takahashi S, Kouzmenko A, et al. The androgen receptor in health and disease. Annu Rev Physiol. 2013;75(1):201-24.

39 Kimura N, Mizokami A, Oonuma T, Sasano $\mathrm{H}$, Nagura H. Immunocytochemical localization of androgen receptor with polyclonal antibody in paraffin-embedded human tissues. Histochem Cytochem. 1993 May;41(5):6718.

40 Yeh S, Tsai MY, Xu Q, Mu XM, Lardy H, Huang KE, et al. Generation and characterization of androgen receptor knockout (ARKO) mice: an in vivo model for the study of androgen functions in selective tissues. Proc Natl Acad Sci USA. 2002 Oct;99(21):13498-503.
41 Kawano H, Sato T, Yamada T, Matsumoto T, Sekine K, Watanabe T, et al. Suppressive function of androgen receptor in bone resorption. Proc Natl Acad Sci USA. 2003 Aug; 100(16): 9416-21.

42 Sato T, Matsumoto T, Kawano H, Watanabe $\mathrm{T}$, Uematsu Y, Sekine K, et al. Brain masculinization requires androgen receptor function. Proc Natl Acad Sci USA. 2004 Feb;101(6): 1673-8.

43 Altuwaijri S, Lee DK, Chuang KH, Ting HJ, Yang Z, Xu Q, et al. Androgen receptor regulates expression of skeletal muscle-specific proteins and muscle cell types. Endocrine. 2004 Oct;25(1):27-32.

44 Ikeda Y, Aihara K, Sato T, Akaike M, Yoshizumi M, Suzaki Y, et al. Androgen receptor gene knockout male mice exhibit impaired cardiac growth and exacerbation of angiotensin II-induced cardiac fibrosis. J Biol Chem. 2005 Aug;280(33):29661-6.

45 Lin HY, Xu Q, Yeh S, Wang RS, Sparks JD, Chang C. Insulin and leptin resistance with hyperleptinemia in mice lacking androgen receptor. Diabetes. 2005 Jun;54(6):1717-25.

46 Lai JJ, Lai KP, Zeng W, Chuang KH, Altuwaijri S, Chang C. Androgen receptor influences on body defense system via modulation of innate and adaptive immune systems: lessons from conditional AR knockout mice. Am J Pathol. 2012 Nov;181(5):1504-12.

47 Huang CK, Tsai MY, Luo J, Kang HY, Lee SO, Chang C. Suppression of androgen receptor enhances the self-renewal of mesenchymal stem cells through elevated expression of EGFR. Biochim Biophys Acta. 2013 May; 1833(5):1222-34.

48 Foradori CD, Weiser MJ, Handa RJ. Non-genomic actions of androgens. Front Neuroendocrinol. 2008 May;29(2):169-81.

49 Lösel R, Wehling M. Nongenomic actions of steroid hormones. Nat Rev Mol Cell Biol. 2003 Jan;4(1):46-56.

50 Asuthkar S, Elustondo PA, Demirkhanyan L, Sun X, Baskaran P, Velpula KK, et al. The TRPM8 protein is a testosterone receptor: I. Biochemical evidence for direct TRPM8-testosterone interactions. J Biol Chem. 2015 Jan; 290(5):2659-69.

51 Asuthkar S, Demirkhanyan L, Sun X, Elustondo PA, Krishnan V, Baskaran P, et al. The TRPM8 protein is a testosterone receptor: II. Functional evidence for an ionotropic effect of testosterone on TRPM8. J Biol Chem. 2015 Jan;290(5):2670-88.

52 Pi M, Faber P, Ekema G, Jackson PD, Ting A, Wang $\mathrm{N}$, et al. Identification of a novel extracellular cation-sensing G-protein-coupled receptor. J Biol Chem. 2005 Dec;280(48): 40201-9.

53 Bulldan A, Dietze R, Shihan M, Scheiner-Bobis G. Non-classical testosterone signaling mediated through ZIP9 stimulates claudin expression and tight junction formation in Sertoli cells. Cell Signal. 2016 Aug;28(8):107585.
54 Baxter-Jones AD, Faulkner RA, Forwood MR, Mirwald RL, Bailey DA. Bone mineral accrual from 8 to 30 years of age: an estimation of peak bone mass. J Bone Miner Res. 2011 Aug;26(8):1729-39.

55 Rønne MS, Heidemann M, Schou A, Laursen JO, Bojesen AB, Lylloff L, et al. Tracking of bone mass from childhood to puberty: a 7-year follow-up. The CHAMPS study DK. Osteoporos Int. 2018 Aug;29(8):1843-52.

56 McCormack SE, Cousminer DL, Chesi A, Mitchell JA, Roy SM, Kalkwarf HJ, et al. Association Between Linear Growth and Bone Accrual in a Diverse Cohort of Children and Adolescents. JAMA Pediatr. 2017 Sep; 171(9):e171769.

57 Heaney RP, Abrams S, Dawson-Hughes B, Looker A, Marcus R, Matkovic V, et al. Peak bone mass. Osteoporos Int. 2000;11(12):9851009.

58 Finkelstein JS, Klibanski A, Neer RM. A longitudinal evaluation of bone mineral density in adult men with histories of delayed puberty. J Clin Endocrinol Metab. 1996 Mar;81(3): $1152-5$

59 Finkelstein JS, Neer RM, Biller BM, Crawford JD, Klibanski A. Osteopenia in men with a history of delayed puberty. N Engl J Med. 1992 Feb;326(9):600-4.

60 Kindblom JM, Lorentzon M, Norjavaara E, Hellqvist A, Nilsson S, Mellström D, et al. Pubertal timing predicts previous fractures and BMD in young adult men: the GOOD study. J Bone Miner Res. 2006 May;21(5):790-5.

61 Kuh D, Muthuri SG, Moore A, Cole TJ, Adams JE, Cooper C, et al. Pubertal timing and bone phenotype in early old age: findings from a British birth cohort study. Int J Epidemiol. 2016 Aug;45(4):1113-24.

62 Cousminer DL, Mitchell JA, Chesi A, Roy SM, Kalkwarf HJ, Lappe JM, et al. Genetically Determined Later Puberty Impacts Lowered Bone Mineral Density in Childhood and Adulthood. I Bone Miner Res. 2018 Mar; 33(3):430-6.

63 Bertelloni S, Baroncelli GI, Ferdeghini M, Perri G, Saggese G. Normal volumetric bone mineral density and bone turnover in young men with histories of constitutional delay of puberty. J Clin Endocrinol Metab. 1998 Dec; 83(12):4280-3.

64 Yap F, Högler W, Briody J, Moore B, Howman-Giles R, Cowell CT. The skeletal phenotype of men with previous constitutional delay of puberty. J Clin Endocrinol Metab. 2004 Sep;89(9):4306-11.

65 Vandenput L, Ohlsson C. Estrogens as regulators of bone health in men. Nat Rev Endocrinol. 2009 Aug;5(8):437-43.

66 Mohamad NV, Soelaiman IN, Chin KY. A concise review of testosterone and bone health. Clin Interv Aging. 2016 Sep;11:131724. 
67 Isidori AM, Giannetta E, Greco EA, Gianfrilli D, Bonifacio V, Isidori A, et al. Effects of testosterone on body composition, bone metabolism and serum lipid profile in middleaged men: a meta-analysis. Clin Endocrinol (Oxf). 2005 Sep;63(3):280-93.

68 Junjie W, Dongsheng H, Lei S, Hongzhuo L, Changying S. Testosterone Replacement Therapy Has Limited Effect on Increasing Bone Mass Density in Older Men: a Metaanalysis. Curr Pharm Des. 2019;25(1):73-84.

69 Snyder PJ, Peachey H, Berlin JA, Hannoush P, Haddad G, Dlewati A, et al. Effects of testosterone replacement in hypogonadal men. J Clin Endocrinol Metab. 2000 Aug;85(8): 2670-7.

70 Behre HM, Kliesch S, Leifke E, Link TM, Nieschlag E. Long-term effect of testosterone therapy on bone mineral density in hypogonadal men. J Clin Endocrinol Metab. 1997 Aug;82(8):2386-90.

71 Canale D, Vignali E, Golia F, Martino E, Pinchera A, Marcocci C. Effects of hormonal replacement treatment on bone mineral density and metabolism in hypogonadal patients. Mol Cell Endocrinol. 2000 Mar;161(1-2):47-51.

72 Laitinen EM, Hero M, Vaaralahti K, Tommiska J, Raivio T. Bone mineral density, body composition and bone turnover in patients with congenital hypogonadotropic hypogonadism. Int J Androl. 2012 Aug;35(4):534-40.

73 Finkelstein JS, Klibanski A, Neer RM, Doppelt SH, Rosenthal DI, Segre GV, et al. Increases in bone density during treatment of men with idiopathic hypogonadotropic hypogonadism. J Clin Endocrinol Metab. 1989 Oct;69(4):776-83.

74 Vieira da Costa J, Pereira-Lima JF, da Costa Oliveira M. Bone mineral density in early-onset hypogonadism and the effect of hormonal replacement. J Clin Densitom. 2004;7(3): 334-40.

75 Crabtree NJ, Arabi A, Bachrach LK, Fewtrell M, El-Hajj Fuleihan G, Kecskemethy HH, et al.; International Society for Clinical Densitometry. Dual-energy X-ray absorptiometry interpretation and reporting in children and adolescents: the revised 2013 ISCD Pediatric Official Positions. J Clin Densitom. 2014 AprJun;17(2):225-42.

76 Weaver CM, Gordon CM, Janz KF, Kalkwarf HJ, Lappe JM, Lewis R, et al. The National Osteoporosis Foundation's position statement on peak bone mass development and lifestyle factors: a systematic review and implementation recommendations. Osteoporos Int. 2016 Apr;27(4):1281-386.

77 Tam FI, Huebner A, Hofbauer LC, Rohayem $\mathrm{J}$. Effects of adolescence-onset hypogonadism on metabolism, bone mineral density and quality of life in adulthood. J Pediatr Endocrinol Metab. 2015 Sep;28(9-10):1047-55.

78 Varimo T, Hero M, Laitinen EM, Sintonen H, Raivio T. Health-related quality of life in male patients with congenital hypogonadotropic hypogonadism. Clin Endocrinol (Oxf). 2015 Jul;83(1):141-3.
79 Ebeling PR. Clinical practice. Osteoporosis in men. N Engl J Med. 2008 Apr;358(14):147482.

80 Antonio L, Caerels S, Jardi F, Delaunay E, Vanderschueren D. Testosterone replacement in congenital hypogonadotropic hypogonadism maintains bone density but has only limited osteoanabolic effects. Andrology. 2019 May;7(3):302-6.

81 Houchin LD, Rogol AD. Androgen replacement in children with constitutional delay of puberty: the case for aggressive therapy. Baillieres Clin Endocrinol Metab. 1998 Oct;12(3): 427-40.

82 Mora S, Gilsanz V. Establishment of peak bone mass. Endocrinol Metab Clin North Am. 2003 Mar;32(1):39-63.

83 Tanner JM, Whitehouse RH, Marubini E, Resele LF. The adolescent growth spurt of boys and girls of the Harpenden growth study. Ann Hum Biol. 1976 Mar;3(2):109-26.

84 Perry RJ, Farquharson C, Ahmed SF. The role of sex steroids in controlling pubertal growth. Clin Endocrinol (Oxf). 2008 Jan;68(1):4-15.

85 Simard J, Hubert JF, Hosseinzadeh T, Labrie F. Stimulation of growth hormone release and synthesis by estrogens in rat anterior pituitary cells in culture. Endocrinology. 1986 Nov; 119(5):2004-11.

86 Birzniece V, Ho KK. Sex steroids and the GH axis: implications for the management of hypopituitarism. Best Pract Res Clin Endocrinol Metab. 2017 Feb;31(1):59-69.

87 Nilsson O, Chrysis D, Pajulo O, Boman A, Holst M, Rubinstein J, et al. Localization of estrogen receptors-alpha and -beta and androgen receptor in the human growth plate at different pubertal stages. J Endocrinol. 2003 May;177(2):319-26.

88 Volta C, Ghizzoni L, Buono T, Ferrari F, Virdis R, Bernasconi S. Final height in a group of untreated children with constitutional growth delay. Helv Paediatr Acta. 1988 Nov;43(3): 171-6.

89 von Kalckreuth G, Haverkamp F, Kessler M, Rosskamp RH. Constitutional delay of growth and puberty: do they really reach their target height? Horm Res. 1991;35(6):222-5.

90 Butenandt O, Bechtold S, Meidert A. Final height in patients with constitutional delay of growth and development from tall statured families. J Pediatr Endocrinol Metab. 2005 Feb;18(2):165-9.

91 Cools BL, Rooman R, Op De Beeck L, Du Caju MV. Boys with a simple delayed puberty reach their target height. Horm Res. 2008;70(4): 209-14.

92 Albanese A, Stanhope R. Does constitutional delayed puberty cause segmental disproportion and short stature? Eur J Pediatr. 1993 Apr;152(4):293-6.

93 Poyrazoğlu S, Günöz H, Darendeliler F, Saka N, Bundak R, Baş F. Constitutional delay of growth and puberty: from presentation to final height. J Pediatr Endocrinol Metab. 2005 Feb;18(2):171-9.
94 Rohani F, Alai MR, Moradi S, Amirkashani D. Evaluation of near final height in boys with constitutional delay in growth and puberty. Endocr Connect. 2018 Mar;7(3):4569.

95 Soliman AT, Khadir MM, Asfour M. Testosterone treatment in adolescent boys with constitutional delay of growth and development. Metabolism. 1995 Aug;44(8):1013-5.

96 Zucchini S, Wasniewska M, Cisternino M, Salerno M, Iughetti L, Maghnie M, et al. Adult height in children with short stature and idiopathic delayed puberty after different management. Eur J Pediatr. 2008 Jun; 167(6):677-81.

97 Kelly BP, Paterson WF, Donaldson MD. Final height outcome and value of height prediction in boys with constitutional delay in growth and adolescence treated with intramuscular testosterone $125 \mathrm{mg}$ per month for 3 months. Clin Endocrinol (Oxf). 2003 Mar; 58(3):267-72.

98 Giri D, Patil P, Blair J, Dharmaraj P, Ramakrishnan $\mathrm{R}, \mathrm{Das} \mathrm{U}$, et al. Testosterone Therapy Improves the First Year Height Velocity in Adolescent Boys with Constitutional Delay of Growth and Puberty. Int J Endocrinol Metab. 2017 Mar;15(2):e42311.

99 Zhu J, Chan YM. Adult Consequences of Self-Limited Delayed Puberty. Pediatrics. 2017 Jun;139(6):e20163177.

100 Uriarte MM, Baron J, Garcia HB, Barnes KM, Loriaux DL, Cutler GB Jr. The effect of pubertal delay on adult height in men with isolated hypogonadotropic hypogonadism. J Clin Endocrinol Metab. 1992 Feb;74(2): 436-40.

101 Arkoncel ML, Arkoncel FR, Lantion-Ang FL. A case of Kallmann syndrome. BMJ Case Rep. 2011 Mar;2011:bcr0120113727.

102 Varimo T, Hero M, Laitinen EM, Miettinen PJ, Tommiska J, Känsäkoski J, et al. Childhood growth in boys with congenital hypogonadotropic hypogonadism. Pediatr Res. 2016 May;79(5):705-9.

103 Schober JM. Quality-of-life studies in patients with ambiguous genitalia. World $J$ Urol. 1999 Aug;17(4):249-52.

104 Schönbucher VB, Landolt MA, Gobet R, Weber DM. Health-related quality of life and psychological adjustment of children and adolescents with hypospadias. J Pediatr. 2008 Jun;152(6):865-72.

105 Bertelloni S, Baroncelli GI, Garofalo P, Cianfarani S. Androgen therapy in hypogonadal adolescent males. Horm Res Paediatr. 2010 74(4):292-6.

106 Boas M, Boisen KA, Virtanen HE, Kaleva M, Suomi AM, Schmidt IM, et al. Postnatal penile length and growth rate correlate to serum testosterone levels: a longitudinal study of 1962 normal boys. Eur J Endocrinol. 2006 Jan;154(1):125-9.

107 Feldman KW, Smith DW. Fetal phallic growth and penile standards for newborn male infants. J Pediatr. 1975 Mar;86(3):3958. 
108 Tomova A, Deepinder F, Robeva R, Lalabonova $\mathrm{H}$, Kumanov P, Agarwal A. Growth and development of male external genitalia: a cross-sectional study of 6200 males aged 0 to 19 years. Arch Pediatr Adolesc Med. 2010 Dec;164(12):1152-7.

109 Wang CH, Lin WD, Bau DT, Tsai CH, Liu DC, Tsai FJ. Penile length of normal boys in Taiwan. Acta Paediatr Taiwan. 2006 NovDec;47(6):293-6.

110 Slayton W, Kedar A, Schatz D. Testosterone induced priapism in two adolescents with sickle cell disease. J Pediatr Endocrinol Metab. 1995 Jul-Sep;8(3):199-203.

111 Zargooshi J. Priapism as a complication of high dose testosterone therapy in a man with hypogonadism. J Urol. 2000 Mar;163(3): 907.

112 Albrecht A, Penger T, Marx M, Hirsch K, Dörr HG. Short-term adverse effects of testosterone used for priming in prepubertal boys before growth hormone stimulation test. J Pediatr Endocrinol Metab. 2018 Jan; 31(1):21-4.

113 Lucas-Herald A, Bertelloni S, Juul A, Bryce J, Jiang J, Rodie M, et al. The Long-Term Outcome of Boys With Partial Androgen Insensitivity Syndrome and a Mutation in the Androgen Receptor Gene. J Clin Endocrinol Metab. 2016 Nov;101(11):3959-67.

114 Myhre SA, Ruvalcaba RH, Johnson HR, Thuline HC, Kelley VC. The effects of testosterone treatment in Klinefelter's syndrome. J Pediatr. 1970 Feb;76(2):267-76.

115 Zacharin M, Sabin MA, Nair VV, Dabadghao P. Addition of recombinant follicle-stimulating hormone to human chorionic gonadotropin treatment in adolescents and young adults with hypogonadotropic hypogonadism promotes normal testicular growth and may promote early spermatogenesis. Fertil Steril. 2012 Oct;98(4):836-42.

116 Warne DW, Decosterd G, Okada H, Yano Y, Koide N, Howles CM. A combined analysis of data to identify predictive factors for spermatogenesis in men with hypogonadotropic hypogonadism treated with recombinant human follicle-stimulating hormone and human chorionic gonadotropin. Fertil Steril. 2009 Aug;92(2):594-604.

117 Raivio T, Wikström AM, Dunkel L. Treatment of gonadotropin-deficient boys with recombinant human FSH: long-term observation and outcome. Eur J Endocrinol. 2007 Jan;156(1):105-11.

118 Dwyer AA, Sykiotis GP, Hayes FJ, Boepple PA, Lee H, Loughlin KR, et al. Trial of recombinant follicle-stimulating hormone pretreatment for $\mathrm{GnRH}$-induced fertility in patients with congenital hypogonadotropic hypogonadism. J Clin Endocrinol Metab. 2013 Nov;98(11):E1790-5.

119 Rohayem J, Hauffa BP, Zacharin M, Kliesch S, Zitzmann M; "German Adolescent Hypogonadotropic Hypogonadism Study Group". Testicular growth and spermatogenesis: new goals for pubertal hormone replacement in boys with hypogonadotropic hypogonadism? - a multicentre prospective study of $\mathrm{hCG} / \mathrm{rFSH}$ treatment outcomes during adolescence. Clin Endocrinol (Oxf). 2017 Jan; 86(1):75-87.

120 Welle S, Jozefowicz R, Forbes G, Griggs RC. Effect of testosterone on metabolic rate and body composition in normal men and men with muscular dystrophy. J Clin Endocrinol Metab. 1992 Feb;74(2):332-5.

121 Chasland LC, Knuiman MW, Divitini ML, Murray K, Handelsman DJ, Flicker L, et al. Higher circulating androgens and higher physical activity levels are associated with less central adiposity and lower risk of cardiovascular death in older men. Clin Endocrinol (Oxf). 2019 Feb;90(2):375-83.

122 Tanner JM. Growth and maturation during adolescence. Nutr Rev. 1981 Feb;39(2):4355 .

123 Kelly DM, Jones TH. Testosterone and obesity. Obes Rev. 2015 Jul;16(7):581-606.

124 Nielsen TL, Hagen C, Wraae K, Brixen K, Petersen PH, Haug E, et al. Visceral and subcutaneous adipose tissue assessed by magnetic resonance imaging in relation to circulating androgens, sex hormone-binding globulin, and luteinizing hormone in young men. J Clin Endocrinol Metab. 2007 Jul; 92(7):2696-705.

125 Ishikawa T, Yamaguchi K, Kondo Y, Takenaka A, Fujisawa M. Metabolic syndrome in men with Klinefelter's syndrome. Urology. 2008 Jun;71(6):1109-13.

126 Davis S, Lahlou N, Bardsley M, Temple MC, Kowal K, Pyle L, et al. Gonadal function is associated with cardiometabolic health in pre-pubertal boys with Klinefelter syndrome. Andrology. 2016 Nov;4(6): 1169-77.

127 Sonmez A, Haymana C, Bolu E, Aydogdu A, Tapan S, Serdar M, et al. Metabolic syndrome and the effect of testosterone treatment in young men with congenital hypogonadotropic hypogonadism. Eur J Endocrinol. 2011 May;164(5):759-64.

128 Wang WB, She F, Xie LF, Yan WH, Ouyang JZ, Wang BA, et al. Evaluation of Basal Serum Adrenocorticotropic Hormone and Cortisol Levels and Their Relationship with Nonalcoholic Fatty Liver Disease in Male Patients with Idiopathic Hypogonadotropic Hypogonadism. Chin Med J (Engl). 2016 May;129(10):1147-53.

129 Bhasin S, Brito JP, Cunningham GR, Hayes FJ, Hodis HN, Matsumoto AM, et al. Testosterone Therapy in Men With Hypogonadism: An Endocrine Society Clinical Practice Guideline. J Clin Endocrinol Metab. 2018 May;103(5):1715-44.

130 Dimitriadis GK, Randeva HS, Aftab S, Ali A Hattersley JG, Pandey S, et al. Metabolic phenotype of male obesity-related secondary hypogonadism pre-replacement and post-replacement therapy with intra-muscular testosterone undecanoate therapy. Endocrine. 2018 Apr;60(1):175-84.
131 Barbonetti A, Caterina Vassallo MR, Cotugno M, Felzani G, Francavilla S, Francavilla F. Low testosterone and non-alcoholic fatty liver disease: evidence for their independent association in men with chronic spinal cord injury. J Spinal Cord Med. 2016 Jul;39(4): 443-9.

132 Völzke H, Aumann N, Krebs A, Nauck M, Steveling A, Lerch MM, et al. Hepatic steatosis is associated with low serum testosterone and high serum DHEAS levels in men. Int J Androl. 2010 Feb;33(1):45-53.

133 Gild P, Cole AP, Krasnova A, Dickerman BA, von Landenberg N, Sun M, et al. Liver Disease in Men Undergoing Androgen Deprivation Therapy for Prostate Cancer. J Urol. 2018 Sep;200(3):573-81.

134 Huang G, Bhasin S, Tang ER, Aakil A, Anderson SW, Jara H, et al. Effect of testosterone administration on liver fat in older men with mobility limitation: results from a randomized controlled trial. J Gerontol A Biol Sci Med Sci. 2013 Aug;68(8):954-9.

135 Haider A, Gooren LJ, Padungtod P, Saad F. Improvement of the metabolic syndrome and of non-alcoholic liver steatosis upon treatment of hypogonadal elderly men with parenteral testosterone undecanoate. Exp Clin Endocrinol Diabetes. 2010 Mar;118(3): $167-71$.

136 Gårevik N, Rane A, Björkhem-Bergman L, Ekström L. Effects of different doses of testosterone on gonadotropins, 25-hydroxyvitamin D3, and blood lipids in healthy men. Subst Abuse Rehabil. 2014 Dec;5:121-7.

137 Solbach P, Potthoff A, Raatschen HJ, Soudah B, Lehmann U, Schneider A, et al. Testosterone-receptor positive hepatocellular carcinoma in a 29 -year old bodybuilder with a history of anabolic androgenic steroid abuse: a case report. BMC Gastroenterol. 2015 May; 15(1):60

138 Ohlander SJ, Varghese B, Pastuszak AW. Erythrocytosis Following Testosterone Therapy. Sex Med Rev. 2018 Jan;6(1):77-85.

139 Jones SD Jr, Dukovac T, Sangkum P, Yafi FA, Hellstrom WJ. Erythrocytosis and Polycythemia Secondary to Testosterone Replacement Therapy in the Aging Male. Sex Med Rev. 2015 Apr;3(2):101-12.

140 Coviello AD, Kaplan B, Lakshman KM, Chen T, Singh AB, Bhasin S. Effects of graded doses of testosterone on erythropoiesis in healthy young and older men. J Clin Endocrinol Metab. 2008 Mar;93(3):914-9.

141 Nahata L, Yu RN, Bhasin S, Cohen LE. Management of testosterone therapy in adolescents and young men with hypogonadism: are we following adult clinical practice guidelines? J Pediatr Endocrinol Metab. 2015 May;28(5-6):635-40.

142 Day FR, Elks CE, Murray A, Ong KK, Perry JR. Puberty timing associated with diabetes, cardiovascular disease and also diverse health outcomes in men and women: the UK Biobank study. Sci Rep. 2015 Jun;5(1): 11208. 
143 Conley CS, Rudolph KD. The emerging sex difference in adolescent depression: interacting contributions of puberty and peer stress. Dev Psychopathol. 2009;21(2):593620.

144 Graber JA, Seeley JR, Brooks-Gunn J, Lewinsohn PM. Is pubertal timing associated with psychopathology in young adulthood. J Am Acad Child Adolesc Psychiatry. 2004 Jun;43(6):718-26.

145 Butenandt A, Hanisch G. Testosterone. The transformation of dehydroandrosterone into androstendiol and testosterone; a method for producing testosterone from cholesterin. Hoppe Seylers Z Physiol Chem. 1935; 237:89-98.

146 Ruzicka L, Wettstein A. Synthesis of the testicular hormone (testosterone) (androstene 3-on-17-ol.). Helv Chim Acta. 1935; 18: 1264-75.

147 Nieschlag E, Nieschlag S. Testosterone deficiency: a historical perspective. Asian J Androl. 2014 Mar-Apr;16(2):161-8.

148 Rogol AD, Tkachenko N, Bryson N. Natesto $^{\mathrm{TM}}$, a novel testosterone nasal gel, normalizes androgen levels in hypogonadal men. Andrology. 2016 Jan;4(1):46-54.

149 FDA approves new oral testosterone capsule for treatment of men with certain forms of hypogonadism. Available from: https:// www.fda.gov/news-events/press-announcements/fda-approves-new-oral-testosterone-capsule-treatment-men-certainforms-hypogonadism.

150 Shoskes JJ, Wilson MK, Spinner ML. Pharmacology of testosterone replacement therapy preparations. Transl Androl Urol. 2016 Dec;5(6):834-43.

151 Dunkel L, Quinton R. Transition in endocrinology: induction of puberty. Eur J Endocrinol. 2014 Jun;170(6):R229-39.

152 Wit JM, Balen H V, Kamp GA, Oostdijk W. Benefit of postponing normal puberty for improving final height. Eur J Endocrinol. 2004 Aug; 151(Suppl 1):S41-5.

153 Lee PA. The effects of manipulation of puberty on growth. Horm Res. 2003;60 Suppl $1: 60-7$.

154 Drobac S, Rubin K, Rogol AD, Rosenfield RL. A workshop on pubertal hormone replacement options in the United States. J Pediatr Endocrinol Metab. 2006 Jan;19(1):5564.

155 Nabhan Z, Eugster EA. Hormone replacement therapy in children with hypogonadotropic hypogonadism: where do we stand? Endocr Pract. 2013 Nov-Dec;19(6):968-71.

156 Giagulli VA, Triggiani V, Carbone MD, Corona $\mathrm{G}$, Tafaro $\mathrm{E}$, Licchelli $\mathrm{B}$, et al. The role of long-acting parenteral testosterone undecanoate compound in the induction of secondary sexual characteristics in males with hypogonadotropic hypogonadism. J Sex Med. 2011 Dec;8(12):3471-8.
157 Santhakumar A, Miller M, Quinton R. Pubertal induction in adult males with isolated hypogonadotropic hypogonadism using long-acting intramuscular testosterone undecanoate 1-g depot (Nebido). Clin Endocrinol (Oxf). 2014 Jan;80(1):155-7.

158 Pazderska A, Mamoojee Y, Artham S, Miller M, Ball SG, Cheetham T, et al. Safety and tolerability of one-year intramuscular testosterone regime to induce puberty in older men with CHH. Endocr Connect. 2018 Jan; 7(1):133-8.

159 Brown DC, Butler GE, Kelnar CJ, Wu FC. A double blind, placebo controlled study of the effects of low dose testosterone undecanoate on the growth of small for age, prepubertal boys. Arch Dis Child. 1995 Aug;73(2):1315.

160 Albanese A, Kewley GD, Long A, Pearl KN, Robins DG, Stanhope R. Oral treatment for constitutional delay of growth and puberty in boys: a randomised trial of an anabolic steroid or testosterone undecanoate. Arch Dis Child. 1994 Oct;71(4):315-7.

161 Ahmed SF, Tucker P, Mayo A, Wallace AM, Hughes IA. Randomized, crossover comparison study of the short-term effect of oral testosterone undecanoate and intramuscular testosterone depot on linear growth and serum bone alkaline phosphatase. J Pediatr Endocrinol Metab. 2004 Jul;17(7):941-50.

162 Gregory JW, Greene SA, Thompson J, Scrimgeour CM, Rennie MJ. Effects of oral testosterone undecanoate on growth, body composition, strength and energy expenditure of adolescent boys. Clin Endocrinol (Oxf). 1992 Sep;37(3):207-13.

163 De Sanctis V, Vullo C, Urso L, Rigolin F, Cavallini A, Caramelli K, et al. Clinical experience using the Androderm testosterone transdermal system in hypogonadal adolescents and young men with $\beta$-thalassemia major. J Pediatr Endocrinol Metab. 1998;11 Suppl 3:891-900.

164 Mayo A, Macintyre H, Wallace AM, Ahmed SF. Transdermal testosterone application: pharmacokinetics and effects on pubertal status, short-term growth, and bone turnover. J Clin Endocrinol Metab. 2004 Feb; 89(2):681-7.

165 Rogol AD, Swerdloff RS, Reiter EO, Ross JL, ZumBrunnen TL, Pratt GA, et al. A multicenter, open-label, observational study of testosterone gel $(1 \%)$ in the treatment of adolescent boys with klinefelter syndrome or anorchia. J Adolesc Health. 2014 Jan;54(1): 20-5.

166 Contreras MF, Raisingani M, Prasad K, Franklin B, Shah B. Transdermal testosterone gel for induction and continuation of puberty in adolescent boys with hepatic dysfunction. J Pediatr Endocrinol Metab. 2017 Jan;30(1):105-9.
167 Chioma L, Papucci G, Fintini D, Cappa M. Use of testosterone gel compared to intramuscular formulation for puberty induction in males with constitutional delay of growth and puberty: a preliminary study. J Endocrinol Invest. 2018 Feb;41(2):259-63.

168 Zacharin MR, Warne GL. Treatment of hypogonadal adolescent boys with long acting subcutaneous testosterone pellets. Arch Dis Child. 1997 Jun;76(6):495-9.

169 Kelnar CJ. Treatment of the short, sexually immature adolescent boy. Arch Dis Child. 1994 Oct;71(4):285-7.

170 Lampit M, Hochberg Z. Androgen therapy in constitutional delay of growth. Horm Res. 2003;59(6):270-5.

171 Crowne EC, Wallace WH, Moore C, Mitchell R, Robertson WH, Holly JM, et al. Effect of low dose oxandrolone and testosterone treatment on the pituitary-testicular and GH axes in boys with constitutional delay of growth and puberty. Clin Endocrinol (Oxf) $1997 \mathrm{Feb} ; 46(2): 209-16$

172 Becker D, Wain LM, Chong YH, Gosai SJ, Henderson NK, Milburn J, et al. Topical dihydrotestosterone to treat micropenis secondary to partial androgen insensitivity syndrome (PAIS) before, during, and after puberty - a case series. J Pediatr Endocrinol Metab. 2016 Feb;29(2):173-7.

173 Odame I, Donaldson MD, Wallace AM, Cochran W, Smith PJ. Early diagnosis and management of 5 alpha-reductase deficiency. Arch Dis Child. 1992 Jun;67(6):720-3.

174 Varimo T, Huopio H, Kariola L, Tenhola S, Voutilainen R, Toppari J, et al. Letrozole versus testosterone for promotion of endogenous puberty in boys with constitutional delay of growth and puberty: a randomised controlled phase 3 trial. Lancet Child Adolesc Health. 2019 Feb;3(2):109-20.

175 Zacharin M. Pubertal induction in hypogonadism: current approaches including use of gonadotrophins. Best Pract Res Clin Endocrinol Metab. 2015 Jun;29(3):367-83.

176 Delemarre EM, Felius B, Delemarre-van de Waal HA. Inducing puberty. Eur J Endocrinol. 2008 Dec;159(Suppl 1):S9-15.

177 Bertelloni S, Dati E, Baroncelli GI. Disorders of sex development: hormonal management in adolescence. Gynecol Endocrinol. 2008 Jun;24(6):339-46.

178 Crabtree NJ, Shaw NJ, Bishop NJ, Adams JE, Mughal MZ, Arundel P, et al.; ALPHABET Study Team. Amalgamated Reference Data for Size-Adjusted Bone Densitometry Measurements in 3598 Children and Young Adults-the ALPHABET Study. J Bone Miner Res. 2017 Jan;32(1):172-80.

179 Kreimeier S, Greiner W. EQ-5D-Y as a Health-Related Quality of Life Instrument for Children and Adolescents: The Instrument's Characteristics, Development, Current Use, and Challenges of Developing Its Value Set. Value Health. 2019 Jan;22(1):317. 